\title{
MEMORY STRATEGIES AND ESL VOCABULARY ACQUISITION
}

\author{
Carisma Dreyer and Jeanette Brits
}

This article compares the effectiveness of three learning strategies (memory strategies) for ESL vocabulary acquisition. Four intact ESL classes were divided into one control group and three treatment groups (keyword, semantic, and keyword-semantic). These Afrikaans-speaking standard 6 pupils then received 4 days of instruction. Both multiplechoice and cued-recall instruments were used to measure effects both 1 day and 9 days after instruction. The results indicated that for both the multiple-choice and cued-recall tests the combined keyword-semantic strategy differed statistically significantly as well as practically significantly from the keyword method. The results, therefore, suggest that the combined keyword-semantic strategy increased retention above the other strategies.

Hierdie artikel vergelyk die effektiwiteit van drie taalleerstrategieë (geheue strategieë) vir die aanleer van woordeskat met mekaar. Vier intak Engels tweedetaal klasse is verdeel in een kontrole groep en drie eksperimentele groepe (sleutelwoord, semantiese en 'n kombinasie van die sleutelwoord-semantiese strategieë). ' $n$ Groep Afrikaanssprekende standerd ses leerlinge het vir 'n tydperk van vier dae onderrig in elk van bogenoemde strategieë ontvang. Multikeuse en "cued-recall" instrumente is gebruik om die effek van onderrig beide een dag en nege dae na eksperimentering te bepaal. Die resultate het aangetoon dat die gekombineerde sleutelwoord-semantiese strategie statisties betekenisvol sowel as prakties betekenisvol van die sleutelwoord strategie en die kontrole groep verskil het. Dit wil dus voorkom asof die gekombineerde sleutelwoord-semantiese strategie die mees belowende strategie is ten opsigte van die retensie van woordeskat.

\section{$1 \quad$ INTRODUCTION}

John Carroll (1971:121) pinpoints vocabulary acquisition as one of the basic objectives of schooling:

Although a considerable amount of vocabulary learning is associated with primary language learning in the early years, the acquisition of most of the vocabulary characteristic of an educated adult occurs during the years of schooling, and in fact one of the primary tasks of the school, as far as language learning is concerned, is to teach vocabulary.

Consequently, it is easy to understand why the need to answer questions like "How does word knowledge develop?" and "How can its growth be promoted?" is of such importance to educators.

Oxford (1986) has argued that a greater emphasis needs to be placed on identifying effective second language learning strategies and teaching pupils how to use them. A considerable amount of research has taken place since the late 1970 s concerning vocabulary learning strategies utilized by native speakers of English. Although several people (Martin 1976; Channell, 1980) have proposed various learning strategies for acquiring English vocabulary in a second language environment, to date little research has been carried out regarding the effectiveness of various learning strategies for vocabulary learning in English as a second language. 
This study focuses on the following strategies: keyword, semantic, and the keywordsemantic. In order to determine the effectiveness of these strategies the following questions need to be addressed:

* Will the semantic processing method or the keyword method produce better results over a period of time?

* Will the combined keyword-semantic method facilitate longer term retention than either the keyword or the semantic processing methods used alone?

* Are there any differential effects of the instruction being examined immediately after treatment as compared with longer time spans?

\section{LANGUAGE LEARNING STRATEGIES AND ESL VOCABULARY ACQUISITION}

Learning strategies have been broadly defined as any set of operations or steps used by a learner that will facilitate the acquisition, storage, retrieval, or use of information (Rigney 1978; Dansereau 1985). According to Oxford (1990:8) learning strategies are "specific actions taken by the learner to make learning easier, faster, more enjoyable, more self-directed, more effective, and more transferrable to new situations".

In their discussion of five different views on strategies, Naiman et al. (1975:59) acknowledge that "a consensus on a definition of the term is lacking". Eight years later, Bialystok (1983:100) makes an almost identical statement: "There is little consensus in the literature concerning either the definition or the identification of language learning strategies". The literature for instance refers to learning strategies to as "techniques", "tactics", "potentially conscious plans", "learning skills", "basic skills", and "problem solving procedures" (Wenden 1987:7). These varied designations point to the elusive nature of the term. However, no matter what they are called, "strategies can make learning more efficient and effective" Oxford and Crookall (1989:404).

The problem with vocabulary acquisition for active use lies not just in learning L2 words, but also in remembering them. Though some teachers think vocabulary learning is easy, language learners have a serious problem remembering the large amounts of vocabulary necessary to achieve fluency. Lord (quoted in Hague, 1987) states that "vocabulary is by far the most sizeable and unmanageable component in the learning of any language, whether a foreign or one's mother tongue" because of "tens of thousands of different meanings". According to Oxford (1990:39) memory strategies help language learners to cope with this difficulty. They have a highly specific function in that they enable learners to store and retrieve new information.

Memory strategies often involve pairing different types of material. In language learning, it is possible to give verbal labels to pictures, or to create visual images of words or phrases. Linking the verbal with the visual is very useful to language learning for four reasons. First, the mind's storage capacity for visual information exceeds its capacity for verbal material. Second, the most efficiently packaged chunks of information are transferred to long-term memory through visual images. Third, visual images may be the most potent device to aid recall of verbal material. Fourth, many learners have a preference for visual learning (cf. Goleman, 1986).

While many language learners benefit from visual imagery, others have aural, kinesthetic or tactile learning style preferences and therefore benefit from linking verbal material with sound, motion, or touch. In memory strategies, as in other kinds of learning strategies, "different strokes for different folks" should be the cardinal rule.

Although memory strategies can be powerful contributors to language learning, some research shows that language learners rarely report using these strategies. It, therefore, 
seems necessary that teachers take active steps to teach pupils how to use language learning strategies effectively.

Bahrick (1984) investigated how well English learners remembered Spanish words eight years after they had learnt them. He found that a word that is learnt after only one or two presentations is remembered better than one that takes several presentations to learn. This confirmed the view that the degree to which people remember something depends on how deeply they process it (Craik \& Lockhart, 1972). As one moves from the shallow sensory level of processing to the deeper semantic level, memory traces become more permanent. Repeating words as strings of sounds is low-level processing and badly remembered; working out how words fit in the grammatical structure of the sentence is deeper and leads to better memory; using the meanings of words together within the whole meaning of the sentence is the deepest level of processing and ensures best memory (Bahrick, 1984). It would therefore seem as if retrieval is enhanced by elaboration. Bahrick's approach also suggests that, if teachers want pupils to remember something for periods longer than a year or two, presentations must be given over a number of days. It is how the word is practised that is important, rather than how often.

\section{METHOD OF RESEARCH}

\subsection{DESIGN}

A quasi-experimental nonrandomized control group design (Borg \& Gall, 1989) was used in this study. This design was chosen for two reasons. First, the instructional programme used in this study could not tolerate the disruption of classes to facilitate random assignment of the subjects. Second, in order to make more ecologically valid generalizations to real classroom environments, authentic classroom situations were used with authentic pupils who were presumably learning English with a genuine desire to pass the standard.

One could argue that an experimental design with random assignment of pupils to treatment and control groups would make the findings more generalizable from the point of randomization of individual differences. However, Snow (cited in Borg \& Gall 1989) has argued that fully randomized experimental designs often lack ecological validity due to the unauthentic environments in which studies are carried out. The quasi-experimental design was selected because the intention of this study was to provide practitioners with findings that are closer to their own classroom settings. A control group and three experimental (i.e., treatment) groups were used. Intact classes were used and they were randomly assigned to the various treatment groups. However, the subjects within the classes were not randomly assigned.

\subsection{SUBJEC'TS}

The accessible study population comprised 110 Standard 6 pupils in Brits High School. In this study, four intact classes were used. The classes had a balanced ratio of males and females. The subjects were all Afrikaans-speaking pupils taking English as a second language. A total of 110 pupils received at least some instruction and testing. However, only pupils who received all instruction and testing were considered, leaving a total of 96 subjects.

\subsection{VARIABLES}

In this study, the dependent variable is the ESL learner's vocabulary ability as measured by a multiple-choice test and a cued-recall test. The independent variables are the three strategies used for vocabulary acquisition, namely the keyword, semantic, and keywordsemantic strategies. 


\subsection{INSTRUMENTATION/MATERIALS}

To ensure that the words were unfamiliar to the pupils, they were given a pretest checklist containing 60 words presented in short sentences with minimal contextual clues several days before instruction to eliminate words that pupils already knew. Pupils were asked to rate how well they knew the words on a five-point, Likert-type scale. The 20 words with means greater than 3,5 were eliminated, leaving 40 words for instruction.

Both recognition and cued-recall instruments were used to measure effects of vocabulary acquisition both one day and nine days after treatment. A 40 -item, four-choice multiplechoice test was constructed to test retention. Each item consisted of a sentence requiring the use of one of the target words. The distractors were chosen from among the 40 words to be studied and were the same part of speech as the correct answer (i.e. noun or verb). To test ability to retrieve the target words, a cued-recall measure was used. Subjects were asked to write the definitions of each of the 40 target words which were listed on a test paper.

\subsection{DATA COLLECTION PROCEDURE}

The four ESL classes were divided into three treatment groups: keyword, semantic, and keyword-semantic, and one control group. The keyword class was presented with the new word, its definition, and a keyword. The semantic class was given the new word, its definition, two examples of the use of the word in sentences, and a question which they were required to answer using the new word. The keyword-semantic class received the new word, its definition, the keyword, and the example sentences and question. The control group merely received an explanation of the words. The pupils in each class received a day of instruction on how to use their method as well as a second day of instructional practice testing. Instruction and testing took about 15 minutes each day. For the following four days, each class was given 5 minutes to learn 10 new words followed by an additional 5 minutes to do a cued-recall test. The day after instruction ended, a comprehensive cued-recall test was given. On the following class day, all pupils took a comprehensive multiple-choice test. Nine days later, the cued-recall test was repeated, and the following day the multiple-choice test was repeated.

\subsection{ANALYSIS}

The data were analysed by means of the Statistica programme. In this study, various statistical techniques were used to assess the data.

Analysis of variance (ANOVA) was used to determine if there were any statistically significant differences between the means of variables under discussion when comparing more than two groups of subjects. Follow-up Tukey pair-wise comparison tests were conducted to determine which groups differed statistically significantly from one another.

A relationship can be regarded as statistically significant if the results are significant at the specified alpha (i.e. probability of chance occurrence). Alpha is established as a criterion, and results either meet the criterion or they do not. In behavioural research, alpha is frequently set at $\mathrm{p}<0,05$ or $\mathrm{p}<0,01$ (i.e., the odds that the findings are due to chance are either 5 in 100 or 1 in 100) (cf. Thomas \& Nelson 1990:100-102). A relationship can be regarded as practically significant if the results are of practical value to the researcher, language practitioner or teacher. Cohen (1977) has established various scales according to which a relationship or difference between means can be regarded as practically significant. Cohen's (1977:20-27) effect size d was used to calculate the 
difference between two means. Cohen uses the following scale for the $d$ values:

Small effect $-0,2$

Medium effect $-0,5$

Large effect $-0,8$

\section{RESULTS}

Table 1 presents the descriptive statistics for test type by experimental group and control group.

Table 1: Descriptive statistics for test type by experimental group and control group

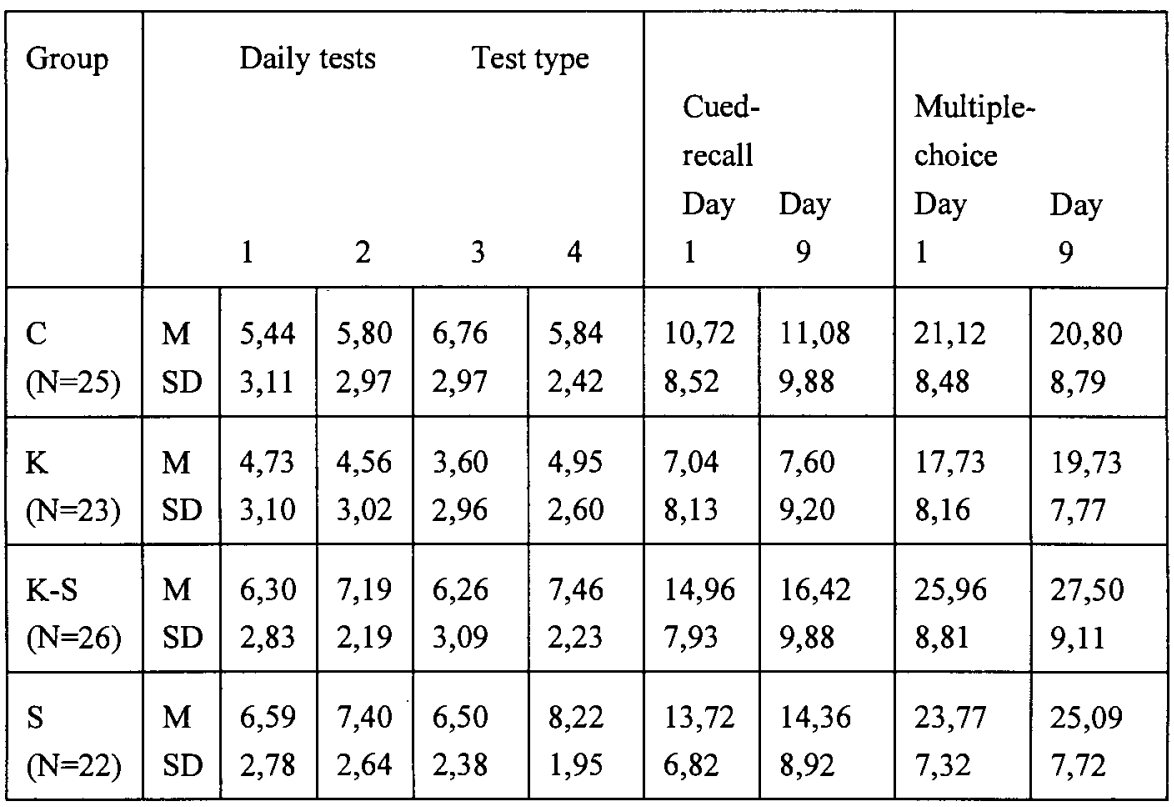

Key:

$\mathrm{C}=$ Control group (Group 1)

$\mathrm{K}=$ Keyword strategy (Group 2)

$\mathrm{K}-\mathrm{S}=$ Keyword-semantic strategy (Group 3)

$\mathrm{S}=$ Semantic strategy (Group 4)

The descriptive statistics reveal that the combined keyword-semantic strategy had higher mean values on the daily tests as well as on the recognition and cued-recall tests when compared to the control group, the keyword strategy group and the semantic strategy group. The semantic strategy group also had higher mean values on all three test types when compared to the control group and the keyword strategy group. This seems to indicate that the keyword-semantic strategy group performed better on these tests than any of the other groups.

Table 2 presents the results of an analysis of variance performed on the data in order to determine if the mean performance of the different strategy groups differed statistically significantly from one another. Follow-up Tukey pair-wise comparisons were also 
conducted to determine where the differences occurred (i.e. between groups 2 and 3, or between 2 and 4, etc.).

Table 2: ANOVA, Tukey and Effect Size Analyses

\begin{tabular}{|l|l|l|l|}
\hline Tests & F-ratio & Tukey & $d$ \\
\hline Daily 1 & $(3,92)=1,87, \mathrm{p}=0,14$ & \\
Daily 2 & $(3,92)=5,54, \mathrm{p}<0,01$ & $3-2^{* *}$ & $\mathrm{~d}=0,87+$ \\
& & $4-2^{* *}$ & $\mathrm{~d}=0,94+$ \\
Daily 3 & $(3,92)=6,01, \mathrm{p}<0,001$ & $2-1^{* *}$ & $\mathrm{~d}=1,06+$ \\
& & $3-2^{* *}$ & $\mathrm{~d}=0,86+$ \\
& & $4-2^{* *}$ & $\mathrm{~d}=0,97+$ \\
Daily 4 & $(3,92)=9,55, \mathrm{p}<0,001$ & $\mathrm{~d}=0,98+$ \\
& & $3-1^{* *}$ & $\mathrm{~d}=0,96+$ \\
Day 1 & $(3,92)=4,74, \mathrm{p}<0,01$ & $\mathrm{~d}=1,25+$ \\
(C-R) & & $3-2^{* * *}$ & $\mathrm{~d}=0,97+$ \\
Day 9 & $(3,92)=4,45, \mathrm{p}<0,01$ & $4-2^{*}$ & \\
(C-R) & & $3-2^{* *}$ & $\mathrm{~d}=0,89+$ \\
Day 1 & $(3,92)=3,97, \mathrm{p}<0,05$ & $3-2^{* *}$ & $\mathrm{~d}=0,93+$ \\
(M-C) & & $3-1^{*}$ & $\mathrm{~d}=0,73$ \\
Day 9 & $(3,92)=4,60, \mathrm{p}<0,01$ & $\mathrm{~d}=0,83+$ \\
(M-C) & & &
\end{tabular}

Key:

\section{Statistical significance}

$* \mathrm{p}<0,05$

\section{Practical significance}

** $p<0,01$

$+d>0,8$ (i.e. large effect)

The results revealed a statistically significant difference $(p<0,01)$ between the combined keyword-semantic strategy group and the keyword strategy group on the daily tests as well as on the cued-recall and multiple-choice tests administered one day after treatment and nine days after treatment. A statistically significant difference $(\mathbf{p}<0,01)$ was found between the semantic strategy group and the keyword strategy group on the daily tests and on the cued-recall test administered one day after treatment. A statistically significant difference $(p<0,01)$ was also found between the combined keyword-semantic strategy group and control group on the multiple-choice test administered nine days after treatment. No difference was found between the semantic strategy group and the combined keyword-semantic strategy group on any of the administered tests. This seems to indicate the superiority of the combined keyword-semantic strategy group and the semantic strategy group over the keyword strategy group and the control group.

Cohen's (1977) effect size $d$ indicates that the differences found between the combined keyword-semantic strategy group and the keyword strategy group on the daily tests as 
well as on the multiple-choice and cued-recall tests were also practically significant $(d>0,8)$ (cf. Table 2). A practical significant difference was also found between the semantic strategy group and the keyword strategy group on the cued-recall test administered one day after treatment. The keyword-semantic group also differed from the control group with a very high medium effect size (i.e., this indicates that it can also be regarded as being practically significant).

In terms of the differential effects for the instructional treatments the results reveal that the combined keyword-semantic strategy group differed statistically significantly as well as practically significantly from the keyword strategy group both immediately after treatment and nine days after treatment on the cued-recall as well as the multiple-choice tests.

If assumptions that recognition tasks (multiple-choice tests) measure information stored in memory and cued-recall tasks reflect facility in retrieving information from memory are warranted (cf. Richardson-Klavehn \& Bjork, 1988), then the results of this study seem to indicate that the combined keyword-semantic strategy produced both stronger memory traces and better retrieval paths than if used on its own.

The effects on retention by the combined keyword-semantic strategy was found in authentic classroom situations. This is important for a strategy to be useful, research must demonstrate that certain learning strategies are not only effective in the laboratory but in the classroom as well.

\section{CONCLUSION}

This study provided some evidence, which supports and augments that of Brown and Perry (1991), to suggest that the combined keyword-semantic strategy promotes more vocabulary acquisition on both the recognition and cued-recall tests ( 1 day and 9 days after treatment) than the keyword strategy and the no strategy (i.e., control group) condition.

These are not the only strategies to be considered, however. Other strategies need to be compared as well, in order to gain an overall picture of the optimal use of learning strategies for vocabulary acquisition. Many language teachers advocate explicit training of language learners in the "how to" of language study. The general goals of such training are to help make language learning more meaningful, to encourage collaborative spirit between learner and teacher, to learn about options for vocabulary learning, and to learn and practise strategies that facilitate self-reliance. Strategy training should not be abstract and theoretical but should be practical and useful for pupils.

It is not yet possible to say with certainty how people learn vocabulary best. However, this research adds to the evidence that learners who receive strategy training generally learn better than those who do not.

\section{REFERENCES}

BAHRICK, HP. 1984. Semantic memory content in premastor: Fifty years of memory for Spanish learned in school. Journal of Experimental Psychology: General, 113(1):1-30.

BIALYSTOK, E. 1983. Some factors in the selection and implementation of communication strategies. In Faerch, C. and C. Kasper (Eds), Strategies in interlanguage communication. London: Longman.

BORG, WR AND MD GALL. 1989. Educational research: An introduction. 5th edition. New York: Longman. 
BROWN, TS AND FL PERRY. 1991. A comparison of three learning strategies for ESL vocabulary acquisition. TESOL Quarterly, 25(4):655-671.

CARROLL, JB. 1971. Development of native language skills beyond the early years. In Reed, C. (Ed), The learning of language. New York: AppletonCentury-Crofts.

CHANNELL, J. 1980. Applying semantic theory to vocabulary teaching. English Language Teaching Journal, 35:115-122.

COHEN, J. 1977. Statistical power analysis for the behavioural sciences. Revised ed. New York: Academic Press.

CRAIK, FIM \& RS LOCKHART. 1972. Levels of processing: A framework for memory research. Journal of Verbal Learning and Verbal Behavior, 11:671684.

DANSEREAU, DF. 1985. Learning strategy research. In Segal, J.W, SF CHIPMAN, and R GLASER (eds), Thinking and learning skills: Relating learning to basic research. Hillsdale, NJ.: Erlbaum.

GOLEMAN, D. 1986. Mental images: New research helps clarify their role. New York Times. August 12.

HAGUE, SA. 1987. Vocabulary instruction: What L2 can learn from L1. Foreign Language Annals, 20(3):217-225.

MARTIN, AV. 1976. Teaching academic vocabulary to foreign graduate students. TESOL Quarterly, 10:91-97.

NAIMAN, N, M FROHLICH AND A TODESCO. 1975. The good second language learner. TESL Talk, 5(1):58-75.

OXFORD, RL. 1986. Second language learning strategies: Current research and implications for practice (TR3). Los Angeles: University of California, Center for Language Education and Research.

OXFORD, RL. 1990. Language learning strategies: what every teacher should know. New York: Harper Collins.

OXFORD, RL. AND D CROOKALL. 1989. Research on language learning strategies: methods, findings and instructional issues. The Modern Language Journal, 73(4):404-419.

RICHARDSON-KLAVEHN, A AND RA BJORK. 1988. Measures of memory. Annual Review of Psychology, 39:475-543.

RIGNEY, JW. 1978. Learning strategies: A theoretical perspective. In O'Neil, HF (Ed), Learning strategies. New York: Academic.

THOMAS, JR AND JK NELSON. 1990. Research methods in physical activity. Champaign, Ill.: Human Kinetics.

WENDEN, A. 1987. Conceptual background and utility. In Wenden, A and J Rubin (eds), Learner strategies in language learning. Englewood Cliffs, NY.: Prentice-Hall. 